\title{
Corporate Governance and Shareholder Activism in India-Theoretical Perspective
}

\author{
Iragavarapu Sridhar \\ Humanities and Social Sciences, IIM Indore, Indore, India \\ Email: isridhar@iimidr.ac.in
}

Received 12 July 2016; accepted 2 August 2016; published 5 August 2016

Copyright (C) 2016 by author and Scientific Research Publishing Inc.

This work is licensed under the Creative Commons Attribution International License (CC BY). http://creativecommons.org/licenses/by/4.0/

(c) (;) Open Access

\begin{abstract}
The origin of division of powers between Board of Directors and Shareholders has been subject of different judicial interpretations. Company law is a standard federal law. Hence, it envisages a clear division of powers between Shareholders and Board of Directors. The purpose of this paper is to analyse the methods and role envisaged for shareholders in corporate governance, given the little incentives and limited means available to them to perform any supervisory function over Board of Directors. The study reports, that it is difficult to tie down any definite role for investors in corporate governance. Corporate governance ought to shift from being a procedural requirement when it comes to addressing the issue of shareholder activism. An implication of the study is to put emphasis for enforcement of shareholder rights through civil proceedings. This can be achieved by introducing substantive provisions codifying duty of care, fiduciary role-playing requirements for Board of Directors.
\end{abstract}

\section{Keywords}

Shareholder Activism, Corporate Governance, Institutional Investors, Powers of Shareholders, Board of Directors

\section{Introduction}

A company is itself a legal person, with an existence independent of that of its members. The company acts through its board of directors and the general meetings [1], which constitute the "organs of the company" and between them exercise all of its powers and functions [2]. The question as to who controls the company between the board of directors and the general meetings has been a source of controversy in various judicial interpretations since the nineteenth century. Historically, the partnership view of company law regarded shareholders as owning and controlling the company and appointing the Board of Directors as a matter of convenience since they cannot manage the company themselves. Directors were therefore regarded as acting on behalf of the 
shareholders and shareholders should therefore be able to dictate to them what they should do. On this reasoning, till about a century ago, it was assumed that the general meetings were the supreme organ of the company and that the board of directors were merely an agent of the company.

In 1906, in the Cunninghame's Case, marking a break from past precedents, it was made clear that the distribution of powers between these two organs was determined by looking at the company's constitution [3]. In this seminal case, the articles of the company provided that the "directors and directors alone shall manage". On these facts, the directors were entitled to refuse to carry out a sale agreement adopted by ordinary resolution in general meeting.

This view has gained an almost axiom like status in company law now [4]. The board does not act as an agent for the members of the company and within the limits of powers conferred upon it by the articles it enjoys sovereignty [5]. The belief for this view is that there exists a division between ownership and control. Therefore, except in matters specifically allotted to the company in the general meeting, directors, and no one else, are responsible for the management of the company. Indeed, one of the principal reasons for the popularity of the company as a legal form for business enterprise is that it enables the shareholders to contribute capital and earn returns without taking part in the management of the company. Therefore, at first instance, it seems surprising that there can exist any such creature as "shareholder activism and corporate governance". It is the purpose of this paper to examine the scope, justifications and possible methods by which shareholders can participate in governance of the companies today. Further, the structure of the paper is as follows. The second section deals with the distribution of powers between the shareholders and the board of directors within the present scheme of the Companies Act. The third section highlights shareholder participation in general meeting, and oppression and mismanagement under Companies Act. The fourth section is the discussion of various aspects identified. The fifth section concludes.

\section{Powers of Shareholders and Board of Directors}

The general meeting enjoys plenary powers and between the board and the general meeting, the powers are divided on the basis of the Companies Act, any other enactment laying down the distribution of powers, the constitution of the company, and the regulations made by the general meeting. If we proceed on the strict application of theory of separation of ownership and control [6], then it is clear that powers of the management will be exercisable only by the board, since it is the board which is in charge of controlling the corporation. However, there might be certain cases where the general meeting has to (or can legitimately) exercise managerial powers. For the purpose of this paper, the term, "managerial power of the general meeting" implies powers exercisable by the general meeting apart from the legislative powers. This would include cases where the powers are vested in the general meeting by the Companies Act or the Constitution of the company. It also includes situation where the concurrence or the consent of the general meeting is required for the acts of the board of directors. There might arise situations where the board of directors are either unable or unwilling to act, and therefore, it is up to the general meeting to discharge the functions of the board. In all the three cases, the General Meeting exercises what can be as its "managerial powers".

In so far as the powers are vested in the general meeting through legislation or the constitution of the company it cannot be doubted, that the shareholders acting through the general meeting are bypassing the classical ownership-control division. The shareholders have a right to be vigilant in safeguarding their investment and putting it in such manner and in the hands of such management which can ensure safety and security of investors [7]. In this case they exercise their elementary right as shareholders. It is important to understand that unlike American law and the law of Continental European countries, English and Indian law do not regard certain functions and powers as managerial and therefore as inherently exercisable only by the Board of directors and inalienable by it [8]. This is evident in the wording of Section 179 of Indian Companies Act, 2013 [9]. Further, there are a number of sections within the companies' legislation where the consent of the general meeting is required before the board can take any positive action or where certain powers have been reserved exclusively to the general meeting ${ }^{1}$. The most important of these is the power of removal of the directors by only a simple resolution. Those who believe in a modern corporation, the board of directors are a "self perpetuating oligarch" [10]. This is a very important power in the hands of the shareholders. If they are dissatisfied with the management of the affairs of the company a simple resolution is enough to remove the directors and therefore there does

${ }^{1}$ It is possible for the articles to concurrently vest the same powers in the members and the board of directors. Since the general meeting is regarded as the superior organ, in the event of a conflict, the decision in the general meeting would prevail over that of the board. 
not exist any chance for an oligarchy like situation arising.

General Powers: Company law provisions both in UK and India provide that the management powers of the directors will be "(subject) to any regulation made by the company in general meeting". Further it is provided by way of a clarification that such a regulation "shall not invalidate any prior act of the directors which would have been valid (sans the regulation)". The difference is that unlike the Indian Companies law, UK Company law provides that it shall be subject to any "directions given by special resolution". The issue which arises in this case is regards the scope of this power of regulation held by the general meeting. But earlier English law, cases have consistently ruled that such a provision does not imply any general power of supervision or management to the general meeting [11]. This has been justified on the ground that a true construction of the articles they do not give members the right to control directors. Studies suggest that the powers of director(s) could be curtailed in future by passing a resolution in general meeting. However it is submitted that these decisions rest on the implied reasoning that such provisions are inconsistent with the principle of division of powers [12]. This position has been attacked by a number of commentators as being both illogical and impractical [13]. An alternative approach will be to recognize that this power to prescribe regulations is nothing but the vestigial remains of the power to make by-law which used to be reserved to members by the deeds of settlement of companies. Such bye-laws are usually procedural and therefore regulations made by general meetings in exercise of power conferred on it by the Companies Act must be confined to procedural matters. As a logical progression, the members in a general meeting can for example when and how board meetings shall be held, but not what shall be done at them. However, although supported by a few commentators, as already discussed the trend of the case law is against such an interpretation.

Shareholders in general has the following powers: 1) to attend meetings of shareholders and exercise voting rights, either personally or through proxy 2) to transfer shares 3) to receive dividend when declared 4) to elect directors 5) to requisition an extraordinary general meeting of the company 6) to have right shares and bonus shares 7) to apply to Tribunal 8) to file class action suits 9) to file a suit in case of any misleading statements in the prospectus.

The Board of Directors of a company shall be entitled to exercise all such powers and to do all such acts as the company is authorized to do. However, this power is subject to powers as given in Companies Act, 2013 and which are to be done by the company in general meetings. Powers of Board of Directors in brief are as follows: 1) to issue securities, including debentures 2) to invest the funds of the company 3) to grant loans or give guarantee or provide security in respect of loans 4) to approve financial statement and the Board's report 5) to borrow monies 6) to diversify the business of the company 7) to appoint and remove key managerial personnel 8) to appoint internal auditor 9) to approve quarterly, half yearly and annual financial statements 10 ) to accept or renew public deposits 11) to authorize buy-back of securities.

Residuary Powers: There arises a legal quandary in situations where the Board is unwilling or unable to act. In such situations, it is permissible for the general meeting to exercise the powers vested in the Board of Directors even though it may be exercising powers which are conferred on the board. There are a number of situations conceivable where the general meeting may be called upon to exercise these "default" or "residuary" powerswhere there is a deadlock on the board; where an effective quorum cannot be obtained either because the directors are disqualified from voting, or because there are no directors; where the transaction in question is beyond the powers of the board. Also, it is important to understand that in these situations the General Meeting is exercising its residuary powers, and therefore it can either ratify the acts of the directors, or authorize the directors to act on their behalf through an ordinary resolution. In either case, since the directors are acting as agents of the general meeting and not as directors of the company, they are governed by the rules of agency.

Applying this logic to the last situation, a distinction has to be drawn between the case where the limitation exists merely to the authority of the directors even though it is within the general authority of the company, for instance if it is within the objects clause of the company; and the case where the limitation is present within the constitution and therefore affects the general powers of the company. In the first instance, the company can act by ratifying the acts of the directors by an ordinary resolution since the directors are only being appointed as the agents of the company [14]. But in the latter case, the constitution, until it is altered, binds the shareholders in general meeting as much as the board, and therefore it must first be altered by special resolution before the altered constitution can be acted upon.

The idea of division of powers and functions between management and ownership is well rooted in company law. However, as we proceed to examine in the next section, this division as well as the actual exercise of ma- 
nagerial powers by shareholders is greatly influenced by their profile, reasons for investment, access to information about the company and other factors. Such factors, it is submitted, go a long way in determining whether a shareholder will exercise his "exit" option and sell his shares or use his "voice" option to actually participate in corporate governance. Furthermore, the role and profile of investors can generally be classified into individual shareholders and institutional shareholders. The next section analyzes the role and profile of both these kinds of shareholders, and examines the respective means and incentives they possess to participate in corporate governance.

\subsection{Cost-Benefit Analysis of Corporate Governance}

The separation of "ownership" and "control" of a modern corporation and the relative dynamics of the two classes of person who form a part of either group that has been discussed above leads to a peculiar situation [15]. Shareholders, as owners have the ability to regulate the activities of the management of their company in two distinct ways - either through their "voice" right or their "exit" right. Dispersed shareholding not only decreases the "owners" cost-benefit incentive of monitoring those who "control" the company, but it also reduces the impact that the shareholder's "voice", exercised through his vote that is attached to ordinary shares, has in the overall scheme of regulation of the management [16]. This classical position of "Berle and Means" was radically affected by the bursting of the "institutional investor" onto the scene [17]. The investment patterns of institutional investors in listed equities have been on exponential incline and can only continue to grow. Well established literature of Berle and Means world extended by [18]; and [19] about modern corporation suggests about the large shareholder's inherent benefits with their shareholdings that must necessarily impact corporate governance in a positive manner given two popular hypothesis - that of "convergence of interest" and "efficient monitoring [20]". The seemingly inherent passiveness that small, variegated shareholders brought to the domain of corporate governance appears at first glance to be swept away by the advent of the institutional investor on the strength of the above hypothesis.

"Convergence of Interest" and "Efficient Monitoring": The allure of exercising the "exit" option with larger shareholding is considerably diminished given that, the institutional investors will be unable to do so, unless they voluntarily opt to sell their shares at prices lower than those that are prevalent in the market [21]. Once the option of easy liquidity is unavailable, automatically the long term interests of the company synchronize with the interests of the institutional shareholder. Further the size of the holding in conjunction with the absence of "exit" creates the necessary incentive for the institutional investor to invest in the time and resources required to research the company in question, understand it better in an endeavor known as "relational investing". Relational investing entails stability and assurance between users and providers of capital [22]. Automatically then, the route that these shareholders will choose to traverse, will be that of employing their considerable "voice". The size of the holdings of the institutional investors necessarily implies that they occupy a position which allows them the luxury of considerable power in terms of voting strength. In addition, they are in a position to wield a great deal of influence over the board of directors by conveying their displeasure over certain activities to the board, directly [23].

However in terms of empirical data available, two interesting features emerge: firstly that the "convergence of interest" and "efficient monitoring" hypothesis of large shareholding institutional investors seem to fail in so far as there appears to be no significant increase in terms of institutional shareholder activism and secondly some studies indicate that their activism where visible has had a negative impact or no apparent impact at all on the front of corporate governance [24]. A large number of reasons surface as to why the argumentation that the agglomeration of shareholding through the mechanism of an institutional investor, in addition to their capacity to carry out research and be well-informed, may not in fact present an accurate representation of the truth as far as activism is concerned. These include the unwillingness of the institutional investor to sacrifice liquidity in exchange for control, the possibility that sheer size need not provide the institutional investor with the necessary expertise to be effectively "active", the aspect of political constraints, an incomplete understanding of the competitive environment in which these investors operate and the problems of entering into potential conflict of interest situations.

Liquidity and Thin Equity: Some institutional investors require a great deal of liquidity owing to their own constituent investors' are being entitled to withdraw from their schemes at short notice. In such situations, the institution cannot tie themselves down with large, illiquid equity stakes in companies, unless they actively propose illiquid investments, in which case their respective share-values trade at prices that are substantially lower 
than their asset worth on liquidation which leaves them vulnerable to hostile takeovers which presents a significant disincentive to actually reduce their liquidity. This in turn determines their investment strategy which is more sympathetic to short-term trading and indexed investing rather than long-term value investing and hence activism for these institutions simply does not measure up in a cost benefit analysis.

Competitive Environment and the Free Rider Problem: The free rider problem stems from the fact that by monitoring, institutional investors provide a public good at a private cost. If institutional investors do expend their resources in monitoring their portfolio companies and ensuring good corporate governance, the cost of which would have to be incurred by the activist institution while the benefits will accrue to other shareholders who have not shouldered the burden of such monitoring. Other shareholders include competitors of the activist institutional investor which has borne the cost of monitoring. It has been argued that as long as the gains from monitoring exceed the costs it makes economic sense for the institutional investor to continue monitoring and the free riders will be a tolerable annoyance [25].

This explanation however, omits to take into account the fact that the comparative gains from investments are as important as absolute gains to an institutional investor in a highly competitive economy and thus the free rider problem in the context of other competitors would serve as a serious disincentive to institutional shareholder activism. However, the free rider problem can be overcome when the institutional investor has a larger stake in the company as the gains from the monitoring are not squandered on passive free riders especially competitors [26].

Perhaps the factor that was often overlooked in the theorization that surrounded institutional investor's activism is that of economic restraint, in that they are rarely rated in absolute terms [27]. The immediate problem that this creates in terms of the potential for activism is that, the efforts of an institutional investor in enriching the corporation in question by monitoring the company, yields benefits not only to itself but to other institutional investors as with, at no tangible cost to them. In effect then, institutional investors are seriously discouraged from pursuing the path of activism in the knowledge that on a percentage basis, monitoring increases returns to the monitoring institutions at a rate that is lower than it does to the passive investors (the free riders) and the market too [28].

Short-Termism or the Myopic Investor Hypothesis: According to this hypothesis, Institutional Investors value short term performance over long term gains since their chief objective is a high investment turnover ratio. They are primarily interested in maximizing the profits of their beneficiaries, and thus prefer to "exit" from a poorly performing stock and invest in a portfolio that yields more lucrative short term gains. This is because Institutional Investors owe a fiduciary duty only to the beneficiaries of their investments. According to P. F. Drucker they do not owe any fiduciary duty towards the companies in which they have invested their fund and thus an assertion that they ought to contribute towards better monitoring of their portfolio companies seems to be bare rhetoric without any economic incentives attached to it. The "short-termism" hypothesis considers shareholders as "bystanders" who do not have the patience or the economic incentive to invest in the improvisation of corporate governance which may provide delayed (if any) benefits. However, there are several English cases which support the view that a trustee who holds a substantial stake in a company has a duty of active involvement and such a trustee is obliged to act as a reasonably prudent person who do in looking after the welfare of those for whom he feels morally obliged to provide. This theory presents that the diversified portfolio of institutional investors is a symptom of myopia amongst institutional investors. A sizable holding in a particular company implies that the investor is "locked in" as a sale of a large stockholding would results in a depression in the market prices of the stock making the "exit" option unattractive and reducing the liquidity of the investment.

Problem of Conflict of Interest: Institutional investors fulfill a dual role of shareholder/investor as well as current or future business provider as far as companies are concerned. This can be explained especially in terms of external pension fund management firms who not only invest in certain companies, but may, in the future manage the pension funds of those very companies. In addition, the situation where a fund manager may also be the provider of other financial services is a very real possibility, and in such situation the client corporation may be unwilling to continue to buy or avail of these if the institution is exercising its right of ensuring corporate governance against the management of the corporation. This may be the latest cause of unwillingness to interfere in an active public manner in the management of the company in question [29]. Furthermore, institutional investors themselves being corporate entities prone to the very same management issues as other corporations reflect a reluctance to draw attention to the very systemic problems. One fear that is often cited as a reason for institutions to shy away from activism has been that being privy to inside information and hence being susceptible 
to claims of insider trading [30]. However it is interesting to note that rather than the institutional investor fearing the heavy hand of the regulator in this regard, the argument against activism from this quarter stems largely from an apprehensive corporate lobby rather than from the institutions themselves.

The position that arises from the discussion above is that there are reasonable number of circumstances that exist which act as deterrents for institutional investors to take an active role in corporate governance. What then is the jurisprudential basis by which one may argue for the imposition of a duty on the institutional investors to play a role in corporate governance? Further, if such an argument can be made then to what extent will such a duty to actively espouse corporate governance be justified?

\subsection{Incentives for Institutional Investor Activism}

Costly Exit: When the "exit" option becomes uneconomical, in the case of large shareholdings of the institutional investors, the better option is to exercise their "voice" towards improving corporate governance practices of the company. Long term gains of such an exercise should be considered.

Regulatory Devices: Certain regulatory devices to make "exit" option less attractive and "voice" alternative more effective have been used to help overcome lethargy amongst institutional investors in the US. This includes the Greenmail Statute which provides for the disgorgement of profits earned by an institutional investor holding more than a $20 \%$ stake in a company if they sell their holdings within 18 months of buying the stake. The underlying policy behind this was the discouragement of investor myopia and short-termism, thus making the exit option unattractive and compelling institutional investor "voice". ment policy of compulsory voting under ERISA (Employment Retirement Income Security Act), under which one of the fiduciary duties of a pension fund is to vote on behalf of its beneficiaries especially if it affects the value of the investment of pension plans. However, this regulation has not been successful in achieving its purpose. Empirical evidence indicates that, such a regulation which seeks to enforce compulsory voting is likely to focus on process rather than substance, it does not in any way ensure informed voting, and in most cases institutional investors voted with the management and the voting is seen as a mere window dressing [31].

The legislative agenda should be to induce institutional investors to overcome the legal and non-legal factors which tilt their incentive towards shareholder passivity. At a policy level the basic principle should be to encourage "voice" and discourage "exit". To this end there may be two approaches, on the one hand a regulation which would make "voice" less costly and on the other a regulation which would make "exit" more expensive. It is contended that the former strategy seems more desirable as it does not adversely interfere with the right to alienation of property, which is one of the fundamental tenets of ownership.

Market Discipline: Another incentive is to reintroduce market discipline. This is because of late there has been a reduction in takeover activity in the market due to the use of devices such as poison pills by self serving management. Since takeover provides a premium-priced exit for holdings of any size institutional investors have an interest in the repeal of poison pill strategies. Further, there has been an increasing trend of institutional investors becoming more vocal in corporate governance issues of their portfolio companies, especially in the US. There now seems to be a change in the nature of institutional investor activism in which, in addition to attacking corporate governance topics individually, investors are trying to gain a more broadly based influence on the board of directors generally. Examples include shadow management committees, independent director slates and the use of outside experts to critique management policy.

Institutional investors owe a duty to their beneficiaries/investors to ensure returns of the highest possibility. In addition they are under an obligation so as to speak - to act as part of the majority for a proper purpose fairly and without oppression. Now considering the first of two above-mentioned duties-most equity that institutional investors hold, is on behalf of others. This places them in the position of fiduciary responsibility as defined by [32] and, which means that they must consider the interests of all sections of people who are their beneficiaries and must scrupulously avoid taking decisions which would not derogate from the same. Now at the threshold level, unless this duty can be reconciled satisfactorily with the second duty, it is increasingly difficult to see how a duty to be actively involved in ensuring a system of corporate governance is either justifiable or feasible. Nevertheless it is quite evident that the structure of institutional investors itself distinguishes them from ordinary shareholders. In this scheme of affairs it is relatively unclear as to how an absolute obligation may be imposed on an institutional investor to take positive action in the interests of corporate governance. It certainly cannot derogate from the institutional fundamental duty that they owe to their beneficiaries to safeguard their interests.

${ }^{2}$ Sunder Sankaran, "Shareholder Activism” available at www.advantageindia.com. 
The question of whether institutions are legally obliged to actively pursue corporate governance centres around their duty of fiduciary office in making active and genuine interventions in the exercise of their power and not from stricter requirements such as obligatory voting. What remains then is to make a convincing argument as to the possibility of institutional investors being placed under an obligation to ensure corporate governance, so long as in doing so, they protect their beneficiaries' investments.

\section{Shareholders Participation in Corporate Governance}

Let us now examine the methods available to shareholders to participate in corporate governance within the Indian Companies Act, 2013. In each of these methods, both the actual procedures as well as the problems arising which hinder or increase the costs of shareholder participation have also been discussed. Following are the methods available within the Indian Companies Act, 2013 for shareholders to participate in corporate governance.

\subsection{General Meeting}

As per Section-100 of the Companies Act, 2013 General Meetings are of three kinds: Annual General Meeting (AGM), Extraordinary General Meeting (EGM) and Class Meeting. What makes the AGM of great significance is that it is a mandatory statutory requirement to hold an AGM at the specified period complying with the conditions laid in Section 96 of Companies Act, 2013. The period between two AGMs can thus not be more than fifteen months and there has to be an AGM in every calendar year. Further, the requirement of submission of Report on AGM containing a fair and correct summary of the proceedings of the meeting has to be compiled with.

What this implies is that the AGM has to be held by the Board of Directors, even if it does not want to which might be the case if the Company has performed badly and hence this being a mandatory requirement itself makes the AGM a powerful tools in the hands of shareholders. Further, the AGM is not just means by which important business is transacted; but also a form in which the shareholders are informed of the important aspects of the functioning of the Company, especially relating to the financial health of the Company. They can question the directors; raise important issues regarding the company; pass resolutions and exercise their most important power with respect to appointment of directors standing for re-election and removal of directors. While most of these transactions can be undertaken in Extra Ordinary General Meetings also, members who may want to raise such issues may not be able to ask for convening the meeting due to the strict requirement of the number of members needed to convene an EGM as specified in Rules 17 of the Companies (Management and Administration) Rules 2014. This is why the mandatory and regular occurrence of an AGM assumes such great significance. Following are the important mandatory matters that have to be dealt with in the AGM.

\subsubsection{Appointment of Directors and Power of Removal of Directors}

Perhaps the most important business transacted in a General Meeting relates to the appointment of directors in the place of those retiring by rotation as, not less than $2 / 3^{\text {rd }}$ of all the Directors of a company are to be appointed by General Meeting and $1 / 3^{\text {rd }}$ of those directors have to retire by rotation every year. Thus, in an AGM, if the shareholders are dissatisfied with a particular director, he will not be reappointed. Furthermore, under Section 169 of Companies Act, 2013, any director of the company can be removed by passing an ordinary resolution at a General Meeting.

The problem as far as exercising the powers of election in an AGM are that firstly in large companies the existing management unless the situation is dire, often command the loyalty of shareholders; simply by virtue of being in office. Further, the existing board of directors has the whole of the companies' resources at their disposal to conduct an elaborate public relations exercise with respect to their re-election. Another tactic that has been used by directors; is to have special voting rights with respect to their shares in the Articles of Association of a company thereby defeating the very purpose of having a re-election. Thus, as has been expressed before in this paper, the board of directors tends to be self-perpetuating body.

\subsubsection{Placing of Accounts, Balance Sheet, Report of Director, Auditor and Corporate Governance Report}

The next important aspect of an AGM is with regard to the placing of the Balance Sheet, Accounts as well as the reports of the director and auditor for the consideration of the meeting. This is important as it is here that the 
most important function of an AGM takes place: informing the shareholders regarding the health of the Company and letting them voice their concerns regarding the same. All the above documents are to be sent to a shareholder twenty-one days before the commencement of the AGM and since these documents are often complicated; this period should be extended so that interested shareholders can understand the affairs of the company. There are other matters to be considered at the AGM, including the appointment of auditors, which is usually a formality of re-appointing the existing auditor unless a member questioning the re-appointment has passed a special resolution and matters like fixing the auditor's remuneration and declaration of dividend.

\subsubsection{Procedure for a General Meeting}

The important aspects of such procedure, as well as the problems arising out of the same and suggested reform have been highlighted in this section.

1) The AGM has to be held in the place of the registered office or city where the registered office is located. This is different from a General Meeting; which can be held at far flung areas discouraging shareholders from attending. A disadvantage however is that an AGM cannot be held on a "public holiday"; which means that shareholders will have to take leave from work and this will reduce attendance at the AGM.

2) A "clear notice" of 21 days is required to be given to shareholders and other parties under Section-101 of Companies Act, 2013. This notice should contain details regarding the kind of business to be transacted at the AGM; but details and explanatory notes are required only in the case of special business. This may however lead to the company undertaking important business, in the guise of ordinary business at the AGM leaving the shareholder unprepared to deal with the same.

3) With regard to the quorum on the AGMs, regulations prescribe that proxies are not counted. What is significant is that such quorum is not required to be present at the adjourned meeting. Further though the statute does not specifically say that the requirement of the quorum is throughout the meeting, it can be inferred that regulations implies an effective quorum is required throughout, the matter transacted and not just the beginning of the meeting.

4) The most controversial aspect of the business of a company is with regard to the right of every member to appoint a proxy. Though, proxies are supposed to facilitate shareholder democracy, proxies can also lead to solicitation of votes by the Board of Directors as the whole machinery is heavily tilted towards the management. This is because even the Board of Directors always strikes the first blow before the opposition can start getting proxies in its favor. Further, proxies do not have the right to speak at meetings and are not counted when a vote by show of hands is taken which can lead to absurd results. However, it is submitted that in view of the fact that members may not be able to attend the AGM; proxies are an essential and further the recent reforms allowing voting by postal ballot/electronic means are a step in the right direction. Apart from the problems seen above, a measure to educate the shareholders about the mechanisms of lodging a proxy vote would be greatly beneficial [33].

5) The next important matter is with regard to member's resolution that can be passed through circulation. In theory this is a powerful weapon in the hands of the shareholders; but is exercised rarely. The reason is due to the timing of such a resolution notice of which has to be given to the company 6 weeks in advance of the general meeting. Considering only a 21 day notice is to be given before taking place of a general meeting and all the important documents and matters are given to shareholders only then; if a shareholder wants to raise a resolution regarding the material circulated it would be impossible to do so. Such resolution require either a substantial shareholding or the interested members to co-ordinate with many others to move the resolution, which is difficult considering records of beneficial ownership of shares are not with the company registers. Further, the company will then provide the notice of such resolutions to all its other members at the expense of the requisitionists.

6) As per Section-169 of Companies Act, 2013, a special notice to be given for removal of directors. It may prove a difficult initiative for shareholders to take. There is just not enough time to let either the company or shareholders make informed decisions, as supplementary information by the director/auditor proposed to be removed must also be given within this time frame.

\subsection{Oppression and Mismanagement under Companies Act 2013}

Another method by which shareholders can exert some influence in the realm of corporate governance is through the provisions of Companies Act 2013 that deal with oppression and mismanagement. On an application by shareholders the Court examines the affairs of the company as conducted by the majority shareholders or the di- 
rectors and whether such conduct is oppressive to the minority shareholders. The oppression will depend on the facts of each case. However, the conduct must be burdensome, harsh and wrongful. Mere lack of confidence between the majority shareholders and the minority shareholders would not be enough unless the lack of confidence springs from oppressive conduct of affairs, and such oppression must involve at least an element of lack of probity or fair dealing to a member in the matter of his propriety rights as a shareholder. By reasons of such acts of oppression, it must be shown that the majority secured pecuniary advantage or wrongfully usurped authority.

Two core principles need to be highlighted in this regard. First, it must be noted that the English Companies Act does not require a minimum number of members to file a petition. It appears that even a single member can file a petition. This on one hand makes the remedy more readily accessible and may on the other hand also leads to frivolous litigation. Companies Act 2013 does not either expressly or by necessary implication indicate that the consent to be accorded there under should be given by member personally. The power to give consent can also be delegated to an agent. It must be kept in mind that if the persons who gave their consent for filing o the petition subsequently withdraw their consent, it does not affect the proceedings. The Company Law Board regulations in this regard are not mandatory and substantial compliance with them is sufficient. Thus where it is clear that the consent of the shareholders is there even though it may not have been expressed clearly, it would not affect the petition. Secondly, both actual and apprehended prejudice is taken care of by English Company Law, while on the other hand, the Companies Act, 2013 talks of very specific circumstances, i.e., change in the management and control, which may lead to the apprehension of prejudice. Thus the scope of Indian Companies Act in this regard is restricted and in reality not too many cases succeed under this category.

\section{Discussion}

The idea of division of powers and functions between management and ownership is well rooted in company law. However, as the discussion above shows, this division becomes untenable at times and therefore a strict distribution of powers has not been carried out. Evidencing historical fact the supremacy of the general meeting in company law is clearly discernable from the case law. However, there is a raging academic debate over the scope of the power of superintendence of the shareholders through general meetings over the management of the corporation. It is submitted that legally speaking, the proposal that this should be recognized as affecting only a procedural power is the most sensible amongst the various position taken. However, it is submitted that there is a lot of merit in the law and economic literature of granting a general power of supervision to the general meeting.

It has been alleged however that this view disregards the differences between large public corporations with widespread and fragmented shareholdings and small and close-knit private corporations. Thus, it might be argued that in many public companies, no one shareholder or group of shareholders can exercise any effective control over the board of directors and therefore the idea of managerial powers of the general meeting is purely illusory. This argument is flawed at two levels. First, if the owners of the shares in a company do not like what the directors are doing, then rather than to try to influence the management of the corporation, they can simply sell the shares in the market. This inherent liquidity and ease of transfer of share ensures that market mechanism will keep a control over the management of the corporation. The market for corporate control and the market for director's employment will align the interests of the directors and the shareholders. Thus, when the stock market is informed that the directors of a company are not acting in the best interests of the shareholders, the price of the company's shares will fall and it will be taken over by new owners who will install new directors to run the business more efficiently. Second and more important, this argument ignores the rise of large institutional shareholders in the corporate world. It is now possible, for the large institutional shareholders to control enough shares to overcome the separation of ownership and control in large public companies and have an influence on their management through exercise of managerial powers in the general meetings.

In purely legal terms it appears to be impossible to tie down institutional investors to any well defined role in corporate governance. This must be viewed in the light of the fact that they are professional investors and that their relationship with any corporation will ultimately be determined by their ability to maximize their economic gains, in the best interest of their beneficiaries. If this result in their exercising their "exit" option rather than persisting with the "voice" option it would be foolhardy to suggest that they nevertheless have an absolute obligation to make interventions in order to further corporate governance. This is not to say that institutional investors must play out the role of mere passive investors. Where it is necessary to make the appropriate incursions into this area, would be in situations where the management of the institutional investor themselves lose sight of 
the fiduciary duty that they owe to their beneficiaries and choose to make decisions which while allowing for the lack of interest for corporate governance, also impact upon the best interests of the full range of beneficiaries. At this stage a recommendation that can certainly be made in order to reduce passivity is that of collective action towards "general-level" broad spectrum systemic changes towards ensuring corporate governance.

Another possible option is to identify shareholders having "significant holdings" and imposing a duty on them to actually vote in the AGM. The sanction to such a duty would however not be derived from actual legal punishment, but introducing an economic incentive by way of a "voting bonus" of a certain percentage of shareholdings, which would be incentive enough for a large shareholder to attend the AGM and exercise their rights. Significant shareholders is to be defined in context of the overall patterns of size of companies as well as shareholder patterns and is to be determined on the basis of shareholders who should have an enhanced obligation to ensure that corporations are managed properly, due to the fact that they have the power to influence the manner in which the company functions. The authors of this proposition give a number of reasons why this should be followed based on economics, political and social reasons. Due to the economic logic that they advance in terms of a workable "voting bonus", it makes us believe that is a solution that could be looked upon to make AGMs serve their true purpose as powerful tool in the hands of shareholders.

It may be submitted that both in strict legal theory and practice, the idea of managerial powers of the general meeting is rational and definitely needs to find a place in the company law jurisprudence. Now the issue arises as to how effective have these managerial powers of the general meetings proved to be in controlling the "agency costs" necessarily associated with the ownership-control dichotomy. In the case of small private companies, there is generally no separation of ownership and control. Even there, in so far as this division leads to imposition of "agency costs" the concept of managerial powers of the general meeting is able to rectify it. In contrast, in large public companies with the rise of institutional shareholdings it is submitted that the law is able to effectively achieve corporate efficiency because of listing requirements.

\section{Conclusion}

As can be observed from the above discussion, the changing role and profile of shareholders as investors has evolved from active owners to a passive investor. Therefore, shareholders today have limited means and little incentive to participate in corporate governance. This is notwithstanding, the powers, as envisaged under the Companies Act, 2013 and the Constitution of the company to check the unbridled powers of the Board of Directors. By nature, equity shareholders are fair-weather friends, not activist crusaders, and this makes shareholder oversight difficult. They may vote with their feet if unhappy with the management and even fellow-investors tend to ignore right-enforcing actions. But given the recent policy trends towards good corporate governance, the role of Board of Directors is indeed gaining focus because of the institution of independent directors, besides; banks and financial institutions can still continue to be conscious keepers. Role of investor protection organization and proxy advisory firms have a definite role to play in inculcating the culture of shareholder activism for better governance. Let it be remembered that governance rights will remain "rights". It should not be changed to duties. In such a case, the profile of the investor does not matter. Forcing institutional investors to take a stand on every issue does not help and on the flip side it may lead to unintended consequence.

\section{References}

[1] French, D., Mayson, S., Mayson, S.W. and Ryan, C.L. (2014) Mayson, French and Ryan on Company Law. Oxford University Press, Oxford. http://dx.doi.org/10.1093/he/9780198716532.001.0001

[2] Pennington, R. (2001) Company Law. Butterworths, London.

[3] Automatic Self-Cleansing Filter Syndicate Co v. Cunninghame 1906245.

[4] Howard Smith Ltd. v. Ampol Petroleum Ltd. 1974 AC 821.

[5] John Shaw \& Sons (Salford) Ltd. v. Shaw 19352 KB 113.

[6] Jensen, M.C. and Meckling, W.H. (1976) Theory of the Firm: Managerial Behavior, Agency Costs and Ownership Structure. Journal of Financial Economics, 3, 305-360. http://dx.doi.org/10.1016/0304-405X(76)90026-X

[7] LICv. Escorts Ltd. 19861 SCJ 38.

[8] Credit Development Pte Ltd. v IMO Pte Ltd. 19932 SLR 370.

[9] Companies Act (2013) Ministry of Company’s Affairs. Government of India, New Delhi. 
http://www.mca.gov.in/Ministry/pdf/CompaniesAct2013.pdf

[10] Davies, P.L. (2008) Gower \& Davies: The Principles of Modern Company Law. Sweet \& Maxwell, London.

[11] Breckland Group Holdings Ltd. v London and Suffolk Properties Ltd. 1989 BCLC 100.

[12] Salmon v. Quin \& Axtens Ltd. 1909 CA 311.

[13] Mackenzie, J.A. (1983) Who Controls the Company? The Interpretation of Table A. Company Law Review, 4, 80-99.

[14] Irvine v Union Bank of Australia (1877) 2 APP CAS 266.

[15] Black, B.S. (1992) Institutional Investors and Corporate Governance: The Case for Institutional Voice. Journal of Applied Corporate Finance, 5, 19-32. http://dx.doi.org/10.1111/j.1745-6622.1992.tb00223.x

[16] Davies, P.L. (1997) Institutional Investors as Corporate Monitors in the UK. Comparative Corporate Governance, 74, 47-76. http://dx.doi.org/10.1515/9783110905045.47

[17] Farrar, J.H. (2001) Corporate Governance in Australia and New Zealand. Oxford University Press, Oxford.

[18] Fama, E.F. and Jensen, M.C. (1983) Agency Problems and Residual Claims. The Journal of Law \& Economics, 26, 327-349. http://dx.doi.org/10.1086/467038

[19] Shleifer, A. and Vishny, R.W. (1986) Greenmail, White Knights, and Shareholders' Interest. The Rand Journal of Economics, 17, 293-309. http://dx.doi.org/10.2307/2555712

[20] Sarkar, J. and Sarkar, S. (2000) Large Shareholder Activism in Corporate Governance in Developing Countries: Evidence from India. International Review of Finance, 1, 161-194. http://dx.doi.org/10.1111/1468-2443.00010

[21] Coffee, J.C. (1991) Liquidity versus Control: The Institutional Investor as Corporate Monitor. Columbia Law Review, 91, 1277-1368. http://dx.doi.org/10.2307/1123064

[22] Charkham, J. and Simpson, A. (1999) Fair Shares: The Future of Shareholder Power and Responsibility. Oxford University Press, Oxford. http://dx.doi.org/10.1093/acprof:oso/9780198292142.001.0001

[23] Miles, L. (2000) Institutional Shareholders: Sleeping Partners in Corporate Governance. Scottish Law \& Practice Quarterly, 5, 210-216.

[24] Lessing, J. (1998) International Investors: Will We See Greater Cooperation between Them Regarding Corporate Governance. Bond Law Review, 10, 376-390.

[25] Rock, E.B. (1991) The Logic and (Uncertain) Significance of Institutional Shareholder Activism. Georgetown Law Journal, 79, 445-506.

[26] Black, B.S. (1990) Shareholder Passivity Re-Examined. Michigan Law Review, 89, 520-608. http://dx.doi.org/10.2307/1289384

[27] Farrar, J.H., Hannigan, B., Furey, N.E. and Wylie, P. (1998) Farrar’s Company Law. Butterworths Publishing Ltd., London.

[28] Gilson, R.J. and Kraakman, R. (1991) Reinventing the Outside Director: An Agenda for Institutional Investors. Stanford Law Review, 43, 863-906. http://dx.doi.org/10.2307/1228922

[29] Keasey, K. and Wright, M. (1997) Corporate Governance: Responsibilities, Risks, and Remuneration. John Wiley and Sons, New York.

[30] Stapledon, G.P. (1996) Institutional Shareholders and Corporate Governance. Clarendon Press, Oxford.

[31] Sullivan, G.R. (1977) The Relationship between the Board of Directors and the General Meeting in Limited Companies. Law Quarterly Review, 93, 569-572.

[32] Charkham, J. (1994) Keeping Good Company: A Study of Corporate Governance in Five Countries. Claredon, Oxford.

[33] Organisation for Economic Co-Operation and Development (1999) OECD Principles of Corporate Governance. OECD. 


\section{Submit or recommend next manuscript to SCIRP and we will provide best service for you:}

Accepting pre-submission inquiries through Email, Facebook, LinkedIn, Twitter, etc.

A wide selection of journals (inclusive of 9 subjects, more than 200 journals)

Providing 24-hour high-quality service

User-friendly online submission system

Fair and swift peer-review system

Efficient typesetting and proofreading procedure

Display of the result of downloads and visits, as well as the number of cited articles

Maximum dissemination of your research work

Submit your manuscript at: http://papersubmission.scirp.org/ 